\title{
TRANSITIVITY ANALYSIS OF KEYNOTE SPEECH OF JOKO WIDODO AT WEF EA 2015
}

\author{
Mardiono
}

\begin{abstract}
International political speeches have played an extremely important role in political environment and take broader public attention due to their political, economy, and cultural values manifested through the language used. SystemicFunctional Grammar introduced and developed by Halliday (1967) sets out that with languages there are ideational meta-function, interpersonal meta-function, and textual meta-function. Hiring the theory of transitivity from Halliday's Systemic Functional Linguistics, this study focuses on analysing Joko Widodo's keynote speech. The aim is to figure out the deeper meaning of the speech through the distributions and so the dominations of the transitivity processes along with their participants. At the same time this study tries to find out the hidden information by analysing the functions of the transitivity processes and the main participants. The qualitative method is employed for the transitivity analysis while the quantitative method is taken to provide the statistic description on the distributions of the types of the process and the participants found. The analysis generates two major findings: First, there are five types of process: material, relational, verbal, mental, existential and the participants found, and no single behavioural process and its participants occurred. Among them, the material process and relational process along with their participants dominate the speech, which makes it well-delivered, more powerful, objective, and convincing. Second, the pronouns 'we, our, and us' are found as the main participants in Joko Widodo's keynote speech that indicate his efforts to draw a close relation between him and his audience so his addressing has succeeded.
\end{abstract}

Keywords: Joko Widodo's keynote speech, participants, process, transitivity analysis

\section{INTRODUCTION}

Language and human lives are all developing through time and time and are inseparable from the practice of human society. There is a variety of different functions of language use, and among which, at the very first stage, it is to express both the inner and outer world of consciousness of people's experiences (Halliday: 1967). Language is actualized through a web of relationships among speakers, their surroundings, and the ways how they use it. Systemic - functional linguistics by Halliday, putting the actual use of language as object of research and to elucidate for the language use, performs three meta-functions of language: ideational, interpersonal, and textual. SFL defines the use of language in social contexts to attain several specific goals. In SFL, the focus is on what language does rather than 
noticing how it does it i.e., the structure of the language.

The leading concept of SFL is transitivity. Transitivity analysis of written discourse has become a feasible method of exploring different types of texts since Halliday employed it for analysing William Golding's the Inheritors in 1971. Since the transitivity system has been able to provide a quantitative analysis of any discourse, which is far more convincing and objective, numbers of scholars prefer using the theory for analysing discourses and have contributed a deep interpretation of the data they have chosen.

Undoubtedly, this theory is beneficial to do any discourse analysis especially the spoken ones such as presidential speeches. It contributes more significance than the written discourse as it is delivered by well-known and highly honoured figures in both, written and spoken, publicized in both, printed and electronic media either government or non-government. For Instance, the President of the republic of Indonesia, Joko Widodo, had delivered a speech on World Economic Forum on East Asia about Indonesia's role and vision on Economic growth of Asia countries.

The World Economic Forum is the world council founded to improving the life quality of nations through cooperation between the government and the private sector in the spirit of global citizenship. Joko Widodo's speech at WEF-EA held in Jakarta was highly appreciated by other countries delegations during the forum. Therefore, the researcher was in a very big curiosity to do further research which focuses more on the transitivity process of keynote speech of Joko Widodo at WEFEA.

A descriptive qualitative method is employed in this study to figure out deeper meaning of the speech through the distributions and dominations of the transitivity processes and their participants. At the same time this study tries to find out the hidden information by analysing the transitivity processes' functions along with the main participants. The qualitative method is employed for the transitivity analysis while the quantitative method is taken to provide the statistic description on the distributions of the process types and the participants in the speech.

\section{METHOD}

In analysing the speech, the researcher uses SFL approach from Halliday. The unit of the analysis of this research is the keynote speech text delivered by President Joko Widodo at The WEF EA in Jakarta, April $20^{\text {th }}, 2015$. This study employed a descriptive qualitative method. Though, the quantitative method is hired to provide the statistic description on the distributions of the process types and the participants while the qualitative method is to analyse the functions of the process types and the personal pronouns used as the main participants in the speech. Halliday (1983) thinks the procedure of stylistic analysis can be divided into three logically ordered phrases: Analysis, Interpretation and Evaluation (Wang: 2010). The researcher analyses the transitivity system used by Joko Widodo in his speech. All information and more data are obtained by watching the video of the speech on the World Economic Forum official YouTube channel at https://www.youtube.com/watch? $v=y n b K W A A u Y F Q \& t=298 s$ and reading the keynote speech script of Joko Widodo from the official website http://www.setneg. 
go.id/baca/index/keynote_speech_presiden_ri_world_economic_forum_on_east Asia_wef_eadi_jakarta_tgl_20_apr_2015.

\section{RESULTS AND DISCUSSION}

\section{The Distributions and the Domination of Transitivity Processes}

There are 125 clauses analysed in this research. From the analysis, it is found that the distributions and the domination of transitivity processes used in Joko Widodo's keynote speech at WEF EA on April 20 2015 in Jakarta are as the following table.

Table 4. 1 Process Types found in the Keynote Speech

\begin{tabular}{lll}
\hline Process & $\begin{array}{l}\text { Frequency of } \\
\text { Occurrence }\end{array}$ & $\begin{array}{l}\text { Percentage } \\
(\mathbf{\%})\end{array}$ \\
\hline Material & 52 & 41.6 \\
Mental & 14 & 11.2 \\
Relational & 39 & 31.2 \\
Behavioural & 0 & 0 \\
Existential & 4 & 3.2 \\
Verbal & 16 & 12.8 \\
Total & $\mathbf{1 2 5}$ & 100 \\
\hline
\end{tabular}

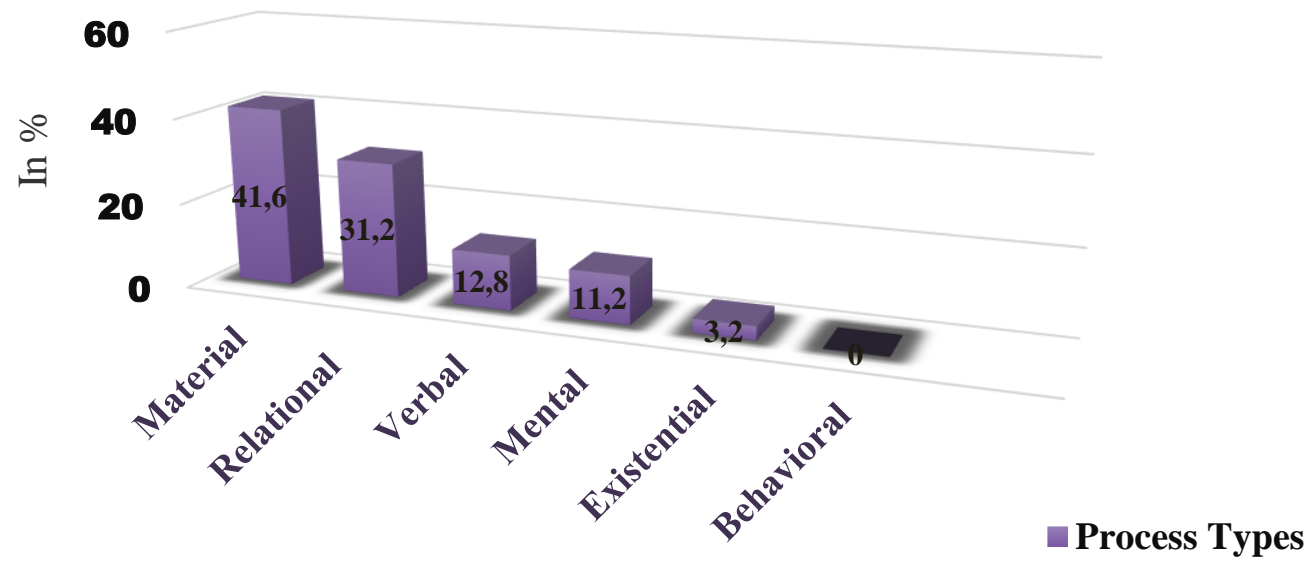

Figure 4. 1 Percentages of Process Types found

It is revealed that overall, in Joko Widodo's keynote speech at World Economy Forum on East Asia, from 6 types, 5 different processes are found, from material as the most, followed by relational on the second place, verbal on the third place, and Existential as the least. From the data, it is clear that there is no single behavioural process found which means Joko Widodo does not mention any of his behaviour as the representative of his nation through his speech and because the 
speech does not necessarily need any. On the contrary, material process seems dominating the trend with 52 occurrences or taking $41.6 \%$ of the total. Material process is a powerful process to state doings and happenings. In the speech, Joko Widodo uses material processes mainly to emphasize his official invitation and guarantee to invest and make profit in Indonesia. To make an ensuring back-up, using material processes, he elaborates what his country has done to deal with the challenging economy environment from time to time since 1980, 1997 (the crisis period), and the following years until 2015 to prevail Indonesia in the global environment. Other than that, material processes are used in his speech initially to welcome his audience (over 700 business, governments, and civil society leaders).

\section{The Distributions and Domination of Participants}

There are 207 participants found in this research. From the data analysis, it is found that the distributions and domination of participants used in Joko Widodo's Keynote Speech are shown in the table below.

Table 4. 2 Participants functions found in the speech

\begin{tabular}{lrr}
\hline \multicolumn{1}{c}{$\begin{array}{c}\text { Participant } \\
\text { Functions }\end{array}$} & $\begin{array}{c}\text { Frequency of } \\
\text { Occurrence }\end{array}$ & $\begin{array}{r}\text { Percent } \\
\text { age (\%) }\end{array}$ \\
\hline Actor & 51 & 24.65 \\
Goal & 17 & 8.21 \\
Recipient & 3 & 1.45 \\
Client & 0 & 0.00 \\
Initiator & 1 & 0.48 \\
Scope & 6 & 2.90 \\
\hline Senser & 14 & 6.76 \\
Phenomenon & 6 & 2.90 \\
\hline Carrier & 32 & 15.46 \\
\hline Attribute & 32 & 15.46 \\
\hline Identified & 7 & 3.38 \\
\hline Identifier & 7 & 3.38 \\
\hline Behaver & 0 & 0.00 \\
\hline Behaviour & 0 & 0.00 \\
\hline Existent & 4 & 1.93 \\
\hline Sayer & 16 & 7.73 \\
\hline Target & 10 & 4.83 \\
\hline Receiver & 0 & 0.00 \\
\hline Verbiage & 1 & 0.48 \\
\hline Total & 207 & 100 \\
\hline & &
\end{tabular}


Figure 4. 2 Percentage of Participant functions found in the speech

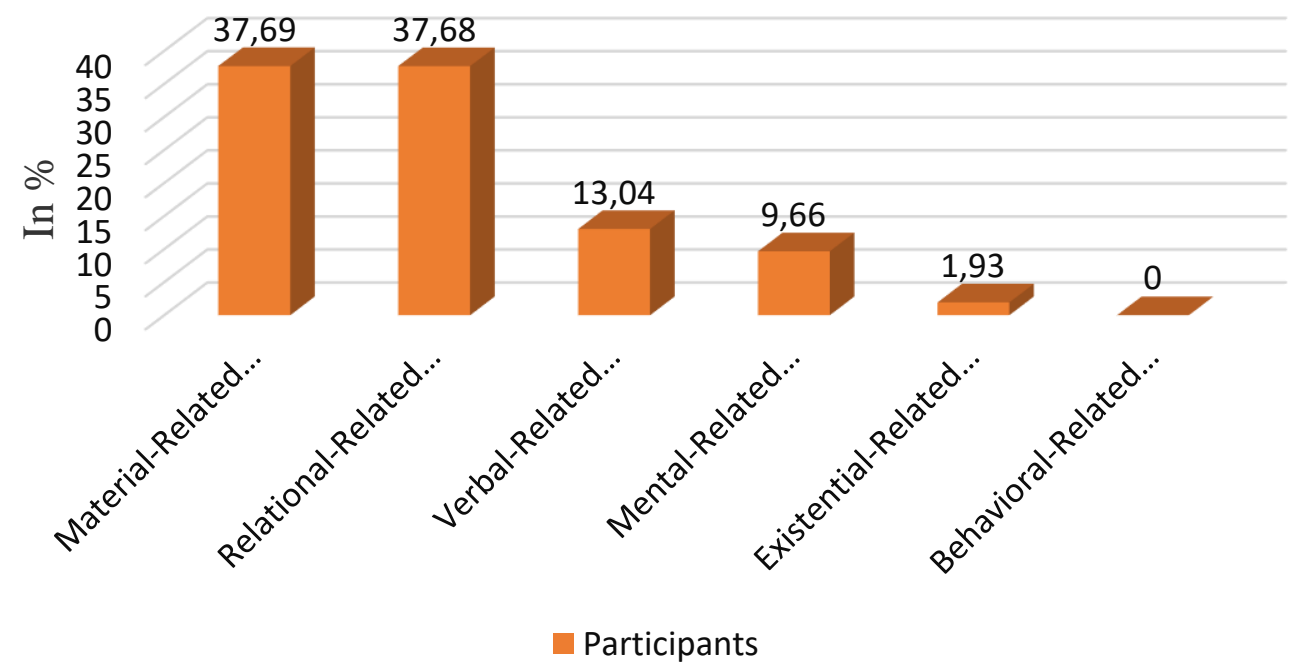

As can be seen from the figure, generally, the most dominant participant is related to the most found process type, the material - related participants which then followed by the relational - related ones. While other participants: verbal, mental, and existential - related participants, following the trend respectively. There are 5 participants of Material occur in the speech, actor, goal, recipient, initiator, and scope which occur 51 times, 17 times, 3 times, once, and 6 times which equals to $24.65 \%, 8.21 \%, 1.45 \%, 0.48 \%, 2.90 \%$, relatively. The frequency of relational related participants occurrence is on the second place which has total of occurrence for 78 times. They are carrier and attribute for 32 times $(15.46 \%)$ each, identified and identifier for 7 times $(3.38 \%)$ each. On the third place, verbal - related participant occurrence is 16 times $(7.73 \%)$ for sayer, 10 times $(4.83 \%)$ for target, and 1 time $(0.48 \%)$ for verbiage which then followed by mental - related participant 14 times $(6.76 \%)$ for senser, 6 times $(2.90 \%)$ for phenomenon, and Existential related for 4 times occurrence of existent or $1.93 \%$. Indeed, there is absolutely no participant of behavioural- related participants in the speech since there is no behavioural process found previously.

\section{The Functions of the Transitivity Processes}

There are five different processes found in this research. From the data analysis, it is revealed that there are some functions of the transitivity processes used in Joko Widodo's keynote speech at WEF EA April 20 $0^{\text {th }}, 2015$ in Jakarta. First, in the keynote speech, material processes are used initially to welcome his audience (over 700 business, governments, and civil society leaders). Then, Joko Widodo implies that Indonesia has to adapt to the increasing competitiveness and volatility in the world economy, including currency fluctuations and falling commodity prices, as well as the shifting of global economic centres in Asia. As stated earlier in the findings, Joko Widodo emphasizes his official invitation and guarantee to invest and make profit in Indonesia. To make an ensuring back-up, 
using material processes too, he elaborates what his country has done to deal with the economy environment from time to time since 1980, 1997 (the crisis period), and the following years until 2015 to prevail Indonesia in the very challenging global environment. Together, audience applaud when he claims, 'We have done it before, and we shall do it again'.

With just almost $10 \%$ less than material, relational process occurs 39 times or takes part for exactly $31.2 \%$. Through relational process, Joko Widodo attracts audience attention by defining facts of world's economy challenges, global transition, opportunities, changes, Indonesia's efforts to survive during the crisis in the past, showing how struggle and confident Indonesia was towards the economy opportunities in Indonesia, and highlighting the facts that Indonesia's strength and power with the people, democracy, economy and history.

Verbal and mental processes take about $12.8 \%$ and $11.2 \%$ or equals 16 times and 14 times of occurrences respectively. Verbal process is used to bridge the gap between his people and audience and to follow up what changes Indonesia people want on their economy sector to the audience. With this, indirectly, verbal process he used has supported him ensuring audience that he and his people welcome investments. Then, Joko Widodo uses the mental process which mainly focus on senses, to create his strong emotional attitude to share and unite positive thoughts so that audience feel the same way as he does.

While with 4 times occurrences or accounted for $3.2 \%$, existential process becomes the least process found in this speech. Existential process is used in Joko Widodo's keynote speech to express his objectivity on changes that they cannot get anything better without any changes, gain without any pain, and that there has to be sacrifice.

\section{The Distributions and the Functions of the Main Participants}

Based on the data analysis, researcher also found that the further dominant participants used in Joko Widodo's keynote speech are the pronouns 'I/youlyour/we/our/us/they/ them'. Therefore, researcher analysed the further distributions and functions of the pronouns to find the hidden information of their functions. It is found that the distributions and the functions of the main participants used in Joko Widodo's Keynote Speech at WEF EA on April 20 $0^{\text {th }}, 2015$ in Jakarta are as shown by the following table.

Table 4. 3 Distributions of the main participants

\begin{tabular}{l|l|l|l|l|l} 
Participants & I/my/me & You /your & We/our/us & They/their/them & total \\
\hline Number & 34 & 15 & 46 & 3 & 98 \\
\hline Percentage & $34.69 \%$ & $15.31 \%$ & $46.94 \%$ & $3.06 \%$ & $100 \%$
\end{tabular}


Figure 4. 3 Percentage of the Distributions of the main participants

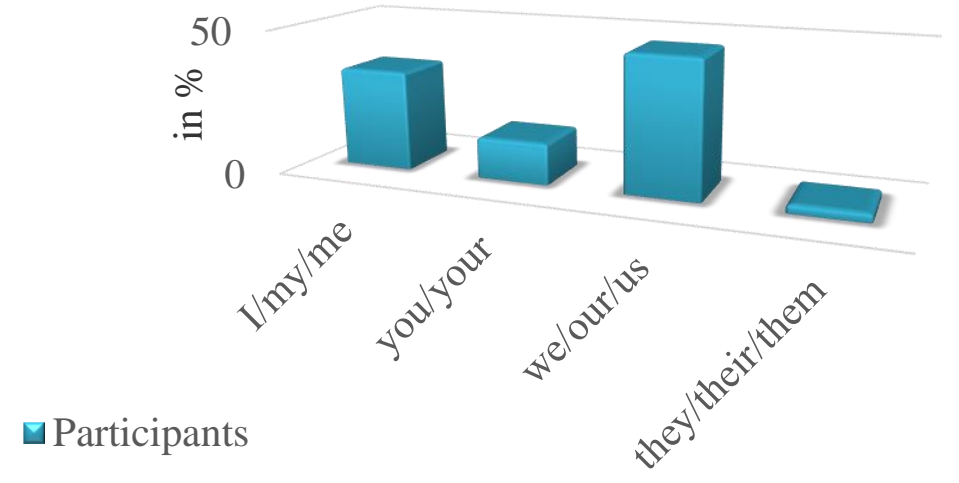

The data show that the pronouns 'we/our/us' and 'I/my/me' are main participants in this speech. The pronouns most often used in this speech is 'we/us/our', with a total of frequency of $(46,46.94 \%)$. The pronouns 'we/our/us' are plural forms of personal pronouns, which indicate a group of people. From this, it shows that Joko Widodo wants to draw closer relation with his audience, and his people (Indonesia). He implies that he is a member of them and may not be separated. Initially, Joko Widodo clearly represents himself as part and the representative of Indonesian people. It is then clearly revealed that through his speech, he takes his people aspiration up with him regarding the economy of the nation and makes it a reason why Indonesia has to be part of the Economy changes in Asia.

The trend is then followed by ' $I / m y / m e$ ' $(34,34.69 \%)$. The pronouns ' $I / m y / m e$ ' are all singular forms. They have strong sense to express any personal opinions or ideas. In this speech, most of them are used to refer to Joko Widodo himself. This personal pronoun makes his political speech become more persuasive, more objective, and impartial.

On the third and last place, there are the pronouns 'you/your' $(15,15.31 \%)$, and the pronouns 'they/their/them' $(3,3.06 \%)$. The pronouns 'you/your' in this speech refer to the addresses of audience, to be more specific, all CEO's, investors, and other invited guests. By using 'you/your', the attention of audience can easily be centralized. This kind of addressing is effective to direct audience to focus on the speech and Joko Widodo has succeeded doing this. The pronouns 'they/their/them' in this speech refer to the people of Indonesia. Joko Widodo uses 'they/their/them' referring his people whose aspiration is taken to make his speech outstanding, reasonable, more objective, and reliable.

\section{CONCLUSION}

To sum up, From the research findings and discussions presented previously, researcher can conclude that,

1. There are 5 different types of processes used in Joko Widodo's keynote speech at World Economic Forum on East Asia on April 20 ${ }^{\text {th }}, 2015$ in Jakarta. In sequence of occurrence frequency, material process is leading with 52 times 
(41.60\%) of occurrence, followed by relational process 39 times $(31.20 \%)$, verbal process 16 times (12.80\%), mental process 14 times $(11.20 \%)$, and existential process 4 times $(3.20 \%)$. Therefore, material process noted as the most frequent process type used in 125 clauses of Joko Widodo's keynote speech at World Economic Forum on East Asia on April 20 ${ }^{\text {th }}, 2015$ in Jakarta.

2. The distributions and dominations of participants are defined in two ways, based on each type of process and based on the main participants. First, from 207 participants, based on each type of the process occurrence, the participants distributions and dominations are in line with the trend of the process types as the findings reveal, material - related participants found for $37.69 \%$ of total participants, followed by the relational - related participant for $37.68 \%$. While 27 times of occurrence (13.04\%), 20 times occurrence (9.66\%), and 4 times of occurrence $(1.93 \%)$ are verbal related, mental related, and existential related, respectively. Researcher also found that the dominant participants used in Joko Widodo's keynote speech are the pronouns 'I/you/your/we/our/us/they/ them'. Second, the participants distributions and dominations based on the main participants, the pronouns 'we/our/us' and 'I/my/me' are the main participants in this speech. The pronouns most often used in this speech is 'we/us/our', with a total of frequency of $(46,46.94 \%)$. The trend is then followed by ' $I / m y / m e$ ' $(34,34.69 \%)$. On the third and last place, there are the pronouns 'you/your' (15, $15.31 \%)$, and the pronouns 'they/their/them' $(3,3.06 \%)$.

3. The functions of the transitivity processes in Joko Widodo's keynote speech are revealed through the findings and discussions.

a. First, Material processes are used initially to welcome his audience (over 700 business, governments, and civil society leaders). Then, Joko Widodo implies that Indonesia must adapt to the increasing competitiveness and volatility in the world economy, including currency fluctuations and falling commodity prices, as well as the shifting of global economic centres in Asia. As stated earlier in the findings, Joko Widodo emphasizes his official invitation and guarantee to invest and make profit in Indonesia. To make an ensuring back-up, using material processes too, he elaborates what his country has done to deal with the economy environment from time to time since 1980, 1997 (the crisis period), and the following years until 2015 to prevail Indonesia in the very challenging global environment.

b. Second, through relational process, Joko Widodo attracts audience attention by defining facts of world's economy challenges, global transition, opportunities, changes, and highlighting the facts that Indonesia's strength and power with the people, democracy, economy, and history. Joko Widodo also shows facts of his nation's economy condition in the past before the crisis (succeeded in crude oil export), during the crisis period, and years after the crisis until then. From that point, at the end, Joko Widodo uses relational process to ensure and show audience that his people, Indonesia, absolutely support investments by telling that people are wise, resourceful, and they want changes. Hearing that, his audience instantly applaud. 
c. Third, Verbal process is used Joko Widodo's speech to bridge the gap between his people and audience and to follow up what changes Indonesia people want on their economy sector to the audience. With this, indirectly, verbal process he uses has also supported him ensuring audience that he and his people welcome investments in his country. Jokowi has succeeded using this process proven by the raising applause from the whole audience twice, in his earlier and the ending part of speech. To be more specific when he says, 'if you have any problem, call me.

d. Fourth, indeed, mental processes used in this speech are not as many as used in such a humanity topic like human right issue or gender equality as it is a political speech which mainly focus on economy sector. But still, mental processes take quite important part in Joko Widodo's keynote speech. He uses the mental process which mainly focus on senses, to create his strong emotional attitude to share and unite positive thoughts so that audience feel the same way as he does.

e. Fifth, since it is a political speech, existential process is less used. It is because using it excessively makes the speech dull and hard to get audience's attention. However, the existential process used in Joko Widodo's keynote speech is to express his objectivity on changes that there can be no progress without changes, that there can be no gain without pain, and that there must be sacrifice.

4. The functions of the main participants used in Joko Widodo's keynote speech are revealed.

a. First, the pronoun we/us/our. Using these pronouns, Joko Widodo clearly represents himself as part or member and the representative of Indonesia. He takes his people aspiration up with him regarding the economy of the nation and makes it a reason why Indonesia has to be part of the Economy changes in Asia. It also indicates that Joko Widodo presents himself as part of the audience who are nations' representatives from many countries in Asia whom he is speaking to.

b. Second, the pronouns ' $I / m y / m e$ ' found refer to Joko Widodo himself. This personal pronoun makes his political speech become more objective, persuasive, and impartial and to clearly imply that as a president, he represents his people, his society, Indonesia.

c. Third, Since the pronoun 'you' can serve in either subject or object, it does not have to be defined separately as they approach the same audience. The pronoun 'you' in Joko Widodo's keynote speech refers to the addresses of audience, to be more specific, all CEO's, investors, and other invited guests. To state a possession of his audience and once to shorten distance between him and audience, he uses the pronoun 'your'. By using 'you/your', the attention of audience can easily be centralized. This kind of addressing is effective to direct audience to focus on the speech and Joko Widodo has succeeded doing this.

d. Fourth, the pronouns 'they/their/them' in this speech refer to the people of Indonesia. Joko Widodo used 'they' referring his people whose aspiration is 
taken to make his speech outstanding, reasonable, more objective, and reliable. There is no other usage of 'they/their/them' found in the rest of the clauses.

Although researcher has tried his best doing the analysis, but still, there are limitations. First, Joko Widodo has had several international speeches since declared as the president of Indonesia, so analysing this speech alone is absolutely not enough to figure out deeper his political intentions. Furthermore, there is no further analysis of the third component (the circumstantial element) done in this transitivity analysis. Therefore, future researcher is really recommended to analyse it as the circumstantial element may give more contribution in transitivity system analysis.

\section{REFERENCES}

Bloor, T., and Bloor, M. 2004. The functional analysis of English. London: Arnold. Christie, F. 2002. Classroom discourse analysis: A functional perspective. London: Continuum

Forum, World Economic [screen name]. (2015, April 23). Indonesia 2015 - East Asia in the New Global Context [Video]. YouTube. https://www.youtube.com/watch?v=ynbKWAAuYFQ\&t=25s

Gerot, L. \& Wignell, P. 1994. Making sense of functional grammar. New South Wales: Gerd Stabler.

Halliday, M. A. K. \& Matthiessen, C. M. I. M. 2004. An introduction to functional grammar $3^{\text {rd }}$ ed. London: Hodder Education.

Halliday, M. A. K., \& Webster, J. 2009. Continuum companion to systemic functional linguistics. New York: Continuum.

Halliday, M.A.K. 1967. Language structure and language function [A]. Lyons, J. (ed.). New Horizons in Linguistics[C]. Middlesex: Penguin.

Halliday, M.A.K. 2001. Language as Social Semiotic: The Social Interpretation of Language and Meaning[M]. Foreign Language Teaching and Research Press.

Halliday, M.A.K. 2014. Halliday's Introduction to Functional Grammar (Fourth Edition). USA: Routledge.

Halliday, M.A.K. 2002. Linguistic studies of text and discourse. London: Continuum International Publishing Group.

Hancock, C. 2005. Meaning -Centered Grammar: An Introductory Text. London: Equinox

Hu Zhuanglin. 1994. Discourse Cohesion and Coherence [M]. Shanghai: Shanghai Foreign Language Education Press. Equinox Publishing Ltd.

Jing, L. 2019. A Case Study of Transitivity Analysis of Trump's Winning Speech Based on Systematic Functional Grammar. International Journal of Language and Linguistics, 7(4), 158. doi: 10.11648/j.ijll.20190704.12

Riris, R. H. 2019. Transitivity Process Analysis of Joko Widodo's Speech at the APEC CEO Summit. International Journal of Innovation Education and Research, 7(5), 01-11. doi: 10.31686/ijier.vol7.iss5.1419 
Setneg.go.id. (2015, 20 April). Keynote Speech Presiden RI, World Economic Forum on East Asia (WEF EA), di Jakarta, tgl. 20 Apr 2015. Retrieved August $20^{\text {th }} \quad 2019$ from https://www.setneg.go.id/baca/index/keynote_speech_presiden_ri_world_e conomic_forum_on_east_Asia_wef_eadi_jakarta_tgl_20_apr_2015।

Wang, Junling. 'A Critical Discourse Analysis of Barack Obama's Speeches.' Journal of Language Teaching and Research, vol. 1, no. 3, 2010, doi:10.4304/jltr.1.3.254-261.

Yujie, Zhu. 'Transitivity Analysis of American President Donald Trump's Inaugural Address.' International Journal of Literature and Arts, vol. 6, no. 2, 2018, p. 28., doi: 10.11648/j.ijla.20180602.11.

Zhang, Yichao. 'Transitivity Analysis of Hillary Clinton's and Donald Trump's First Television Debate.' International Journal of Applied Linguistics and English Literature, vol. 6, no. 7, 2017, p. 65., doi: 10.7575/aiac.ijalel. v.6n.7p.65.

Zhao Yuqiong, Li Fengiie, Transitivity Analysis of David Cameron's Speech in Retaining Scotland, International Journal of Language and Linguistics. Vol. 6, No. 3, 2018, pp. 70-79. doi: 10.11648/j.ijll.20180603.13 